\title{
The BRICS and the Future of $\mathrm{R}_{2} \mathrm{P}$ \\ Was Syria or Libya the Exception?
}

\author{
Oliver Stuenkel \\ Fundação Getulio Vargas \\ oliver.stuenkel@fgv.br
}

\begin{abstract}
This article assesses the BRICS' position on the emerging global norm of the Responsibility to Protect, analyses the year 2011, when all the BRICS occupied a seat on the UN Security Council, and asks how the rise of the BRICS will affect R2P's prospects of turning into a global norm. It argues that while it is generally thought that 'nonWestern' emerging powers are reluctant to embrace $\mathrm{R} 2 \mathrm{P}$, rising powers' views on the norm in question are far more nuanced. Common accusations depicting the BRICS as 'irresponsible stakeholders' are misguided, as emerging powers have supported $\mathrm{R}_{2} \mathrm{P}$ in the vast majority of cases. The BRICS are in fundamental agreement about the principle that undergirds $\mathrm{R}_{2} \mathrm{P}$, and their support for $\mathrm{R}_{2} \mathrm{P}$ 's pillar I and II is absolute. Regarding pillar III, the BRICS at times diverge from Western countries not about the existence of the norm, but about when and how to apply it.
\end{abstract}

\section{Keywords}

Responsibility to Protect - BRICS - UNSC - humanitarian intervention - emerging powers - global norms

This is not your world, they want us to know, and history is not moving in your direction. You will have to reckon with us. We shall indeed. ${ }^{1}$ MiCHE L I gNATIEFF, How Syria Divided the World (2012) 
The dominant position established powers have traditionally held in global affairs is slowly eroding. ${ }^{2}$ For better or worse, the group of those countries with the power to make a difference internationally is changing. As new powers rise to the fore, the world's decision-making elite will most likely become less Western, with fewer common interests, and more ideologically diverse. ${ }^{3}$ This creates a necessity to understand emerging powers' views. ${ }^{4}$ Yet uncertainty remains on many important questions of international affairs, regarding the ideas and perspectives that inform emerging powers as they seek greater visibility and the capacity to influence the global agenda. ${ }^{5}$ One of the issues profoundly affected by this process is the 'Responsibility to Protect' concept, an issue largely dominated by established powers at both the policy and the academic level. ${ }^{6}$ While several non-Western powers and thinkers supported the creation of $\mathrm{R}_{2} \mathrm{P}$ early on, and while $\mathrm{R}_{2} \mathrm{P}$ was adopted at the $2005 \mathrm{UN}$ World Summit unanimously, many analysts still identify a 'collective opposition' to

1 Michael Ignatieff, 'How Syria Divided the World', 11 July 2012, http://www.nybooks.com/ blogs/nyrblog/2012/jul/11/syria-proxy-war-russia-china, accessed 18 February 2013.

2 Randall Schweller, 'Emerging Powers in an Age of Disorder', Global Governance, 17/3: 285-297 (2011).

3 Simon Serfaty, 'Moving into a Post-Western World', The Washington Quarterly, 34/2: 7-23 (2011).

4 There is no consensus on what constitutes an emerging power or a rising power. While China is at times called a rising power (see, for example, G. John Ikenberry, 'The Future of the Liberal World Order', Foreign Affairs, 9o/3: 56-68 (2011), and Ann Florini, 'Rising Asian Powers and Changing Global Governance', International Studies Review, 13/1: 24-33 (2011). Others argue that it is well-established within today's institutions such as the UN Security Council see Alastair Iain Johnston, 'Is China a Status Quo Power?' International Security, 27/4: 5-56 (2003). Brazil and India are at times called 'middle powers' see Chris Alden, Marco Antonio Vieira, 'The new diplomacy of the South: South Africa, Brazil, India and trilateralism', Third World Quarterly, 26/7: 1077-1095 (2005), 'rising powers' see, for example, Andrew Hurrell, 'Lula's Brazil: a rising power, but going where?', Current History, 107/706: 51-57 (February 2008)) or 'emerging powers' see Stephen Philip Cohen, India: Emerging Power (Washington, DC: Brookings Institution Press, 2002), the latter two of which will be used interchangeably here, as is commonly done. See, for example, Schweller, 'Emerging Powers in an Age of Disorder', pp. 285-297.

5 Randall Schweller and Xiaoyu Pu, 'After Unipolarity: China's Visions of International Order in an Era of U.S. Decline', International Security, 36/1: 41-72 (2011).

6 Thomas G. Weiss and Rama Mani, 'R2P's Missing Link, Culture', Global Responsibility to Protect, 3/4: 451-472 (2011). At the same time, non-Western thinkers have made important and seminal contributions to the concept of R2P, such as Francis Deng and the UN Secretary General Kofi Annan. 
the norm among emerging powers, particularly when putting it into practice involves the use of force. ${ }^{7}$ If emerging powers such as China, India and Brazil - which could, over the next decades, be the world's first, third and fourth largest economies respectively - seem to remain ambiguous about $\mathrm{R}_{2} \mathrm{P}$, what does this mean for the future of the norm? With the power of both NATO and the United States significantly limited in a 'Post-Western World', 8 are policy makers in the BRICS countries ${ }^{9}$ willing to assume the responsibility to not only tolerate, but to actively implement and strengthen R2P? Pointing out that the future of R2P depends on the BRICS, David Bosco wrote in 2011,

the fissure in the UN between a Western-led interventionist group and a 'sovereignty bloc' led by Moscow and Beijing, but with real appeal to key emerging powers like Brazil, South Africa and India (...) may be one of the most critical dynamics at the UN. For the moment, the West still has the pull to carry the day. Whether that will be true a decade from now is anyone's guess. ${ }^{10}$

Bosco clearly does not expect emerging non-Western powers to be willing to 'pull to carry' and actively sustain R2P as a global norm.

This article starts out by analysing the political consequences of the current shift of power from the United States and Europe towards the BRICS (1). It then proceeds to analyse the BRICS' position vis-à-vis R2P by chronicling the year 2011, when all the BRICS were part of the UN Security Council, and by describing

See, for example, Rahul Rao, Third World Protest: Between Home and the World (New York: Oxford University Press, 2010), p.86. See also: Zach Paikin, 'Responsibility to Protect and the new calculus of genocide', 18 December 2012, http://www.ipolitics.ca/2012/12/18/responsibility-to-protect-and-the-new-calculus-of-genocide, accessed 18 February 2013. And Michael Ignatieff, 'How Syria Divided the World'.

8 Serfaty, 'Moving into a Post-Western World', pp. 7-23.

9 South Africa was invited to join the BRICS club in December 2010. This article will refer to the group as the BRICS, with a capital 'S', and include South Africa in the analysis. Whenever the article specifically refers to the grouping prior to South Africa's inclusion, I will use 'BRICs (without South Africa)'. The BRICs' attempts to institutionalise have created a fundamental confusion regarding the term. While 'BRICs' mainly represents a Goldman Sachs category of emerging economies for some, for others it stands for the institutional structure that has emerged from it, represented by the yearly BRICS Leaders Summits.

10 David Bosco, 'Abstention games on the Security Council', 17 March 2011, http://bosco .foreignpolicy.com/posts/2011/03/17/abstention_games_on_the_security_council, accessed 18 February 2013 . 
the BRICS' views of each of R2P's three pillars (2). While discussing the BRICS as an entity implies the risk of surface skimming, it is also a necessity to test the common sweeping claims made about rising powers and the future of R2P. Finally, considering the evidence gathered, the article seeks to assess how emerging powers' positions on $\mathrm{R}_{2} \mathrm{P}$ will influence the global debate about the subject, and whether the BRICS' voting behaviour vis-à-vis Libya or Syria was more representative of their overall stance. Do current changes in the global distribution of power imply the end of $\mathrm{R}_{2} \mathrm{P}$ as we know it, as some argue that the Syrian case suggests? (3).

\section{Towards a Post-Western World}

2001 proved to be an important year in international relations for multiple reasons. Aside from the terrorist attacks on September $11^{\text {th }}$ and the ensuing decade-long 'War on Terror', 2001 saw the birth of both the Responsibility to Protect $\left(\mathrm{R}_{2} \mathrm{P}\right)$ and the BRICs concept. The emergence of $\mathrm{R}_{2} \mathrm{P}$ and the BRICs symbolise a dual transformation of international affairs: $\mathrm{R}_{2} \mathrm{P}$ points to a fundamental reconfiguration of the role of sovereignty, and the BRICS term represents a historic process of multipolarization. These two trends do not only seem irreversible, but they also occurred remarkably quickly. ${ }^{11}$

In the mid-199os, there was no clear consensus about whether and when it was justified to violate another country's sovereignty if that country proved unwilling or unable to protect its citizens. At the same time, unipolarity seemed to be the dominant characteristic of the global system, and few expected rising powers to play any significant international role in the near future. ${ }^{12}$

Yet in the years after their 2001 creation, both concepts - $\mathrm{R} 2 \mathrm{P}$ and the BRICs gained momentum. The influence of a paper about the BRICS (then still without South Africa) published by Goldman Sachs in 2003 surpassed the limits of the financial world, helping the BRICS term turn into a buzzword in international politics. ${ }^{13}$ In 2009 the BRICS' leaders met for the first time for an official Summit. In 2010, Goldman Sachs called the first ten years of the 21st century

\footnotetext{
11 This does not mean that the BRICS' rise as individual actors is irreversible, but the term symbolises a global shift of power in more general terms.

12 Charles Krauthammer, 'The Unipolar Moment', Foreign Affairs, 70/1: 23-33 (1990/1991).

13 Hui Fang Cheng, Margarida Gutierrez, Arvind Mahajan, Yochanan Shachmurove and Manuchehr Shahrokhi, 'A future global economy to be built by BRICs', Global Finance Journal, 18/2: 143-157 (2007). See also Gillian Tett, 'The Story of the Brics', 15 January 2010, http://www.ft.com/intl/cms/s/o/112ca932-ooab-11df-ae8d-oo144feabdco.html\# axzz2BGrtRplR, accessed 1 November 2012.
} 
the 'BRICs Decade.' ${ }^{14} \mathrm{R}_{2} \mathrm{P}$, for its part, also rose to prominence faster than many had anticipated. Coined in 2001 by the International Commission on Intervention and State Sovereignty (ICISS) - which made a meaningful effort to include views from the Global South, such as roundtables in the BRICS countries $^{15}$ - the concept was adopted unanimously by heads of state and government at the 2005 UN World Summit. On this occasion, heads of state expressed the 'willingness to take timely and decisive collective action' to protect populations from genocide, war crimes, ethnic cleansing and crimes against humanity through the Security Council, when peaceful means prove inadequate and national authorities are manifestly failing to do it. Gareth Evans writes that according to the historian Martin Gilbert, the Summit symbolised 'the most significant adjustment to sovereignty in 360 years.' 16

In 2009, the same year that the BRICS turned into a political reality, the UNSC reaffirmed the principle (Resolution 1894), and the UN established a Joint Office for the Prevention of Genocide and the Responsibility to Protect. ${ }^{17}$ A little less than a decade after their creation, both R2P and the BRICS have turned into household names in international politics. ${ }^{18}$

On the one hand, these two trends seem to go hand-in-hand. The increased prominence of global challenges such as climate change, failed states, poverty and mass atrocities contributed to a growing consensus that emerging countries such as Brazil, India and China were indispensable in the effort to develop meaningful solutions. ${ }^{19}$ Global summits could no longer claim legitimacy and inclusiveness without inviting Brazil, Russia, India and China. While the United States' National Intelligence Council's 2005 'Global Trends' report had still predicted that the United States would remain the 'single most powerful actor economically, technologically and militarily,,20 the 2009 issue predicted

14 Dominic Wilson and Alex L. Kelston, Swarnali Ahmed, 'Is this the BRICS decade?' Goldman Sachs Global Economics, Issue No. 10/03 (May 2010), p. 2.

15 Alex J. Bellamy, Global Politics and the Responsibility to Protect. From Words to Deeds (London: Routledge, 2011), p. 14.

16 Gareth Evans 'The Responsibility to Protect in Action', The Stanley Foundation Courier, Number 74 (Spring 2012), p. 4.

17 Alex Bellamy, 'R2P - Dead or Alive?' in Malte Brosig (ed.), The Responsibility to Protect From Evasive to Reluctant Action? The Role of Global Middle Powers, (Pretoria, South Africa: Institute for Security Studies, 2012), p. 11.

18 Keith Porter, Marking then years of the Responsibility to Protect', The Stanley Foundation Courier, Number 74: 2 (Spring 2012), p. 2.

19 Andrew Hurrell, 'Hegemony, Liberalism and Global Order: What space for would-be powers?', International Affairs, 82 /1: 3 (2006).

20 National Intelligence Council, In Mapping the Global Future - Report of the National Intelligence Council's 2020 Project, 2004, p. 8. 
'a world in which the US plays a prominent role in global events, but (...) as one among many global actors. ${ }^{21}$ The transition from the G8 to the G2o is one of the most powerful symbols of this shift towards a more multipolar order. Aside from making up $43.3 \%$ of the global population and a quarter of the earth's territory, the BRICS (without South Africa) had been responsible for $36.3 \%$ of world GDP growth in PPP terms during the first decade of the century. ${ }^{22}$

Paradoxically, however, these two parallel developments also stand in significant tension, for the BRICS are generally seen to be among the most reluctant members of the international community to support the Responsibility to Protect. ${ }^{23}$ Despite support from emerging powers for $\mathrm{R}_{2} \mathrm{P}$ numerous times, the debates about questions that may imply the use of force if a government is unable or unwilling to protect its citizens from mass atrocities, has been, in the eyes of many, dominated by pro-interventionist established powers and prosovereignty emerging powers. Russian and Chinese unwillingness to tolerate a UNSC resolution critical of the Assad regime, fearing it could be used as a pretext for another, Libya-like intervention aimed at regime change, led to a strong sense of paralysis on the question about how to respond to the atrocities committed in Syria. Brazil, India and South Africa seemed to largely agree with the Russian position during the $4^{\text {th }}$ BRICS Summit, where the BRICS heads of government jointly called on established powers to 'respect Syrian independence, territorial integrity and sovereignty. ${ }^{24}$ Celso Amorim, Brazil's former Foreign Minister, made some of the strongest arguments against $\mathrm{R}_{2} \mathrm{P}$, famously calling it the 'droit d'ingérence in new clothes'.25 This comment was made in the context of the Iraq War, which had a damaging effect on what emerging powers thought about $\mathrm{R}_{2} \mathrm{P}^{26}$ 'The rift on the Council', a Western diplomat argued in November 2011, 'is national sovereignty versus interference':27 It was implicitly understood that this was meant as a general distinction between a prointerventionist West and a reluctant rest. This clear distribution of roles was so

21 National Intelligence Council, In Global Trends 2025: A Transformed World, NIC 2008-003, November 2008, p. 2. Gideon Rachman makes a similar argument in 'Is America's new declinism for real?', Financial Times, 24 November 2008.

22 Wilson, Kelston and Ahmed, 'Is this the BRICS decade?', p. 3.

23 Ignatieff, 'How Syria Divided the World'.

24 'BRICS Summit: Delhi Declaration', March 2009, article 21, http://www.cfr.org/brazil/ brics-summit-delhi-declaration/p27805, accessed 23 November 2013.

25 Matias Spektor, 'Humanitarian Interventionism Brazilian Style?', Americas Quarterly, 6/3: 54-55 (2012).

26 Bellamy, Global Politics and the Responsibility to Protect. From Words to Deeds, p. 12.

27 Barbara Plett, 'UN Security Council middle powers' Arab Spring dilemma, 8 November 2011, http://www.bbc.co.uk/news/world-middle-east-15628006, accessed 18 February 2013. 
stark that advocacy groups made an explicit attempt to 'de-westernise' R2P. As Steve Crawshaw of Human Rights Watch (HRW) commented as early as 2007, 'if ( $\mathrm{R} 2 \mathrm{P})$ comes across smelling of the U.S. and EU, then we have lost the argument before starting. In a way, lighting the fire in the South may be most important.'28 Matias Spektor confirms that 'if notions of civilian protection are going to become fixtures in the emerging normative landscape, then they will have to be embraced by major rising powers, first among them the members of the BRICS (Brazil, Russia, India, China, and South Africa). ${ }^{29}$

Are the BRICS ready to embrace $\mathrm{R}_{2} \mathrm{P}$ ? Can $\mathrm{R}_{2} \mathrm{P}$ survive once the United States - to this day the only actor capable of implementing large-scale humanitarian interventions - will be, as is predicted, merely 'one of many actors', and the BRICS assume a more dominant position? Is Michael Ignatieff correct when predicting that 'as new powers like Brazil, India and China rise to the top of the international order, their resistance to intervention will become increasingly influential', implying that the stalemate over the situation in Syria, rather than the action taken in Libya, is an indicator of things to come? ${ }^{30}$

\section{The BRICS and R2P}

Prior to the report by the International Commission on Intervention and State Sovereignty (ICISS) in 2001, the BRICS were, in general, quite suspicious of those who argued for a doctrine of 'contingent sovereignty', which implied that a nation's sovereignty depended on its willingness and capacity to protect its citizens. ${ }^{31}$ While Bellamy rightly points out that 'sovereignty as responsibility' was not a Western notion per se, the only countries in the Global South that pioneered the idea were African Union members. Except for South Africa, which joined the BRICS in December 2010, none of the BRICS played an active part in promoting the concept. ${ }^{32}$

In the debates prior to the UN World Summit in 2005, when the non-African BRICS governments began to study the concept in earnest, India threatened to

28 Human Rights Center, The Responsibility to Protect. Moving the Campaign Forward, University of California, Berkeley, October 2007, p. 13.

29 Spektor, 'Humanitarian Interventionism Brazilian Style?'

$30 \quad$ Süddeutsche Zeitung Special Supplement, 'Munich Security Conference', 3 February 2012.

31 Stewart Patrick, 'The role of the US Government in Humanitarian Intervention', p. 15 in: Stuart Elden, 'Contingent Sovereignty, Territorial Integrity and the Sanctity of Borders', SAIS review, 26/1: 11-24 (2006).

32 Bellamy, Global Politics and the Responsibility to Protect. From Words to Deeds, p. 13. 
turn into the principal spoiler, when its Permanent Representative Nirupem Sen openly challenged $\mathrm{R}_{2} \mathrm{P}$ 's legal and moral foundations, thus almost derailing the process. As Bellamy recalls, however, in the end, India was 'not prepared to scuttle the whole summit by rejecting the RtoP.'33

After the successful inclusion of $\mathrm{R}_{2} \mathrm{P}$ as part of articles 138 and 139 in the summit outcome document (which was the product of the largest-ever gathering of heads of state and government), China argued that it had, in fact, not agreed to the idea after all, and that the World Summit agreement merely committed states to continue the debate about $\mathrm{R}_{2} \mathrm{P}$. Brazil temporarily adopted a similar position. ${ }^{34}$ It was largely due to fear of the Russian and the Chinese veto that $\mathrm{R}_{2} \mathrm{P}$ was actually not used more frequently in the years after the summit. 35

After the 2005 UN World Summit, it took six months of intense discussions for the UN Security Council to adopt Resolution 1674, which did little more than reaffirm the responsibility to protect. ${ }^{36}$ By the time the resolution passed, Brazil, which by then had frequently voiced its opposition to the concept, had left the Security Council. ${ }^{37}$ In 2007, the Human Rights Center at the University of Berkeley listed in a report so-called 'backsliding countries' - those that had 'shifted their stance regarding the $\mathrm{R}_{2} \mathrm{P}$ mandate since agreeing to its basic principles at the 2005 World Summit'. The list of 11 countries included China, India, Russia and South Africa. ${ }^{38}$ The report also states that 'in Asia, neither governments nor NGOs have embraced $\mathrm{R}_{2} \mathrm{P}$, due to their belief that $\mathrm{R}_{2} \mathrm{P}$ will compromise state sovereignty.' 39 Of the NGOs listed that promote $\mathrm{R}_{2} \mathrm{P}$, not a single one was based outside of the West. During the first four years of $\mathrm{R}_{2} \mathrm{P}$ 's existence, the BRICS' stance on the matter seemed thus to be marked by scepticism, caution, and the occasional willingness to obstruct the advancement of the concept.

This general narrative seemed valid to many observers as the decade drew to a close. The UN Secretary General's 2009 report did not seek to reinterpret

33 Ibid., p. 23.

34 Ibid., p. 28.

35 Ibid.

36 Ibid.

37 It must, however, be noted that the UNSC was referencing $\mathrm{R}_{2} \mathrm{P}$ in this period, for example in Resolution 1706 on Darfur, when China abstained on the grounds that Sudanese consent had not been secured. (Bellamy, Global Politics and the Responsibility to Protect. From Words to Deeds, p. 29)

38 Human Rights Center, The Responsibility to Protect. Moving the Campaign Forward, 2007, Introduction.

39 Ibid., p. 12. 
the results of the World Summit, but address questions of how to implement its recommendations - and according to several observers, the reports' strong focus on pillars one and two diluted its core message, yet was thought to be necessary to secure support from reluctant states - an indicator of how uncertain UN officials were at the time about the most reluctant states' points of view.

During the 2009 General Assembly debate, the President of the General Assembly appointed the Indian Nirupem Sen, one of the most outspoken critics of $\mathrm{R}_{2} \mathrm{P}$, as special advisor on the responsibility to protect. This appointment led to a highly critical concept paper which pointed out that 'colonialism and interventionism used responsibility to protect arguments. ${ }^{40}$ In the same year, the UN Security Council was largely thought not to have passed a resolution on the humanitarian crisis in Guinea due to China's and Russia's opposition to what those two called an interference in Guinea's domestic affairs ${ }^{41}$ - indicating that the two BRICS with permanent seats in the UN Security Council hold somewhat different views about $\mathrm{R}_{2} \mathrm{P}$ than the other three members of the BRICS.

As a consequence, the discussion about $\mathrm{R}_{2} \mathrm{P}$ today continues to be largely seen in the context of a pro-interventionist Global North and a pro-sovereignty Global South, together with the BRICS bloc. As Michael Ignatieff pointed out in the early days of the Syria crisis, 'the responsibility to protect doctrine was crafted after Kosovo to bridge the gap between the global North and the global South on intervention.' Considering the debates after Libya and the stalemate about Syria, he observes that 'these North-South bridges are still not built. ${ }^{\prime 2}$ Indeed, $\mathrm{R}_{2} \mathrm{P}$ is often seen as a Western concept. Despite the intellectual foundations of the principle being attributed to several non-Western thinkers such as Francis Deng from Sudan - and the African norm of 'non-indifference' which indirectly led to $\mathrm{R}_{2} \mathrm{P}^{43}$ - the vast majority of thinkers who contribute to the debate hail from rich developed countries in the Global North. ${ }^{44}$ In addition, in particular after 2005, emerging powers have often criticised $\mathrm{R}_{2} \mathrm{P}$ and have in some instances sought to undermine its development into a global norm. ${ }^{45}$ Hostile governments - though not the BRICS - have attacked the norm using arguments of cultural specificity, arguing that the West was seeking to

\footnotetext{
40 Bellamy, Global Politics and the Responsibility to Protect. From Words to Deeds, p. 43.

41 Ibid., p. 63.

42 Michael Ignatieff, 'How Syria Divided the World'.

43 Mohamed Sahnoun has argued that $\mathrm{R}_{2} \mathrm{P}$ is a distinctly African contribution to human rights. In 'Africa: Uphold Continent's Contribution to Human Rights, Urges Top Diplomat', 21 July 2009, http://allafrica.com/stories/printable/200907210549.html, accessed 18 February 2013.

44 Serena K. Sharma, RtoP at Ten Years', Global Responsibility to Protect, 3/4: 383-386 (2011).

45 Weiss and Mani, 'R2P's Missing Link, Culture', p. 453.
} 
impose 'certain ideological conceptions of human rights' on the poor. ${ }^{46}$ As a consequence, comments like the one made by Chris Keeler, arguing that 'the $\mathrm{BRIC} / \mathrm{IBSA}$ countries are beginning to unite around scepticism ( of $\mathrm{R}_{2} \mathrm{P}$ ), countering western enthusiasm, 47 have been common since R2P's inception.

\section{The BRICS' Views are More Nuanced}

Yet, despite the seemingly overwhelming evidence, the BRICS' attitude towards $\mathrm{R}_{2} \mathrm{P}$ is far more complex and nuanced than many Western analysts believe. China, Russia, Brazil, South Africa and India all supported the concept of $\mathrm{R}_{2} \mathrm{P}$ at the UN World Summit in 2005 and several times since then - in fact, the BRICS have supported $\mathrm{R}_{2} \mathrm{P}$ far more often than not in the UNSC. As the analysis below shows, the BRICS' support for pillar I and pillar II is absolute, a notion that became increasingly clear when the BRICS reacted relatively positively to the UN Secretary General's 2009 report. The same was true in 2011, when the BRICS collectively voted in favour of resolutions invoking the responsibility to protect vis-à-vis conflicts in the Central African Republic, Guinea Bissau, Sudan and Côte d'Ivoire, among others. ${ }^{48}$

Already at the 2005 Summit, South Africa actively encouraged other African nations to support $\mathrm{R}_{2} \mathrm{P}^{49}$ China has supported several UNSC resolutions referring to $\mathrm{R}_{2} \mathrm{P}$ since the Libya controversy. Thus $\mathrm{R}_{2} \mathrm{P}$ can no longer easily be dealt with as a North-South issue. ${ }^{50}$ The Indian government has frequently used the concept of $\mathrm{R}_{2} \mathrm{P}$ in its rhetoric, such as when calling on the Sri Lankan government to protect its civilians. The Russian Foreign Minister Sergey Lavrov's decision to refer explicitly to $\mathrm{R}_{2} \mathrm{P}$ in justifying an intervention in Georgia in August 2008 (though thereby clearly misinterpreting the concept) shows that Russia in principle agrees with the notion that violating another country's sovereignty may be justified if that country commits mass atrocities against its own citizens. This is irrespective of the fact that Russia's argument of the risk of an imminent genocide in Georgia was rejected by virtually all governments and

46 UN Commission on Human Rights, In Responses of Government and Agencies to the Report of the UN Special Representative for Internally Displaced Persons, E - CN - 4. 1993, SR.40, 1993. Chris Keeler' 'The End of the Responsibility to Protect?', 12 October 2011,http://www .foreignpolicyjournal.com/2011/10/12/the-end-of-the-responsibility-to-protect, accessed 18 February 2013. IBSA refers to the trilateral grouping of India, Brazil and South Africa.

48 Anne Orford, 'From Promise to Practice? The Legal Significance of the Responsibility to Protect Concept', Global Responsibility to Protect, 3/4: 400-424 (2011), p. 401.

49 Chris Landsberg, 'Pax South Africana and the Responsibility to Protect', Global Responsibility to Protect, 2: 436-457 (2010), p. 443.

5o Edward Luck, 'The Responsibility to Protect: The First Decade', Global Responsibility to Protect, 3/4:1-13 (2011). See also Ramesh Thakur, 'Emerging Powers and the Responsibility to Protect after Libya', NUPI Policy Brief, 2012, p. 2. 
experts - if Moscow regarded $\mathrm{R}_{2} \mathrm{P}$ as fundamentally wrong, it would not have used the term to defend its own actions. ${ }^{51}$ Much to the contrary, Moscow used $\mathrm{R}_{2} \mathrm{P}$ to legitimise its intervention, recognizing the norm's reputation. Brazil, for its part, has begun to engage with $\mathrm{R}_{2} \mathrm{P}^{52}$ and briefly acted as a norm entrepreneur when launching the concept of 'Responsibility While Protecting.53 And South Africa, perhaps most active of all, has been instrumental in negotiating the shift from 'non-intervention' to 'non-indifference' in Africa during the 1990s and 2000s. ${ }^{54}$

\section{The BRICS and the West Disagrees on How to Intervene, Not Whether}

When analysed carefully, it becomes clear that while they are often depicted as villains, shirkers and obstructionists, the BRICS have often declined to assume a leading role in opposition to R2P. For example, during the 2009 General Assembly debate, only four countries (Cuba, Venezuela, Sudan and Nicaragua) called for a renegotiation of the 2005 agreement, while the BRICS adopted a more moderate line of argument - they thus clearly cannot play the negative role that is so often given to them in the international media. Partly as a consequence, Alex Bellamy suggests that despite the criticism, $\mathrm{R}_{2} \mathrm{P}$ has never been more accepted than today. ${ }^{55} \mathrm{He}$ argues that the heated debates around $\mathrm{R}_{2} \mathrm{P}$ is not about whether genocide, ethnic cleansing, war crimes or crimes against humanity should be prevented, but rather how they should be prevented. ${ }^{56}$ And indeed, it is here where established powers and the BRICS most strongly disagree. The question of how to protect civilians is a highly complex matter, and the lack of disagreement would probably be more worrisome than the debates that are currently taking place between established powers and emerging powers. The BRICS are aligned with established powers on most aspects of the Responsibility to Protect, a fact that often eludes commentators who argue that the BRICS do not agree with R2P.57 Merely focusing on emerging powers'

51 Elena Jurado, 'A Responsibility to Protect?', New Statesman, 15 August 2008, http://www .newstatesman.com/asia/2008/08/russia-international-georgia-2, accessed 18 February 2013 .

$5^{2}$ Kai Michael Kenkel, 'Brazil and R2P: Does Taking Responsibility Mean Using Force?', Global Responsibility to Protect, 4/1: 5-32 (2012), p. 28.

53 Spektor, 'Humanitarian Interventionism Brazilian Style?'.

54 Landsberg, 'Pax South Africana and the Responsibility to Protect', abstract.

55 Alex Bellamy, 'R2P - Dead or Alive?' in Malte Brosig (ed.), The Responsibility to Protect From Evasive to Reluctant Action? The Role of Global Middle Powers, p. 11.

56 Alex Bellamy, 'Libya and the Responsibility to Protect: The Exception and the Norm', Ethics and International Relations, 25/3: 263-269 (2011), p. 265.

57 Liu Tiewa, 'China and Responsibility to Protect: Maintenance and Change of Its Policy for Intervention', The Pacific Review, 25/1: 153-173 (2012), p. 166. 
Westphalian outlook also risks overlooking meaningful changes in the BRICS' outlook that have taken place over the past years. China has begun to review its formerly unconditional view on sovereignty. ${ }^{58}$ Perhaps worried that its economic interests in post-Gaddafi Libya would be threatened if it were to be singled out as the old regime's staunchest ally, China decided not to veto resolution 1973 in March 2011 to employ all necessary measures to protect civilians in Libya. ${ }^{59}$ Even more surprising, Chinese diplomats met the Libyan rebels in Qatar and Benghazi, possibly because a posture of non-interference is increasingly at odds with its global economic presence. ${ }^{60}$ Naturally, such change comes slowly given that due to China's domestic political situation, the government is likely to continue condemning any revolution abroad for fear of encouraging an uprising at home.

India, traditionally one of the most stalwart defenders of the principle of sovereignty, has shown flexibility regarding Libya as well. India's decision not to vote against resolution 1973 implies that it is ready to support intervention in some specific instances. Rather than siding with Moscow and Beijing, India also voted in favour of the defeated draft resolution S-2012-77 condemning the Syrian government. ${ }^{61}$

Brazil's views on sovereignty have also changed. As Matias Spektor writes, Brazil's stance on intervention is 'in flux' ${ }^{62} \mathrm{He}$ argued that while the traditional thinking was still strong, 'many in Brasília already regard as legitimate the suspension of the sovereign rights of governments that are unwilling or unable to care for their own citizens.' This situation, according to him, 'was unthinkable only few years ago.' In the same way, Kai Kenkel points out that 'Brazil is no longer a vocal detractor of $\mathrm{R}_{2} \mathrm{P}{ }^{\prime} 63$

$5^{8}$ The Economist, 'China's evolving foreign policy: The Libyan dilemma', 10 September 2011, http://www.economist.com/node/21528664, accessed 18 February 2012.

59 The Economist made this argument at the time: Ibid. Chinese foreign policy makers, however, declined to comment on the issue during interviews (Interviews with Chinese diplomats, 2012).

6o The Economist, 'China's evolving foreign policy: The Libyan dilemma', 10 September 2011, http://www.economist.com/node/21528664, accessed 22 July 2013. In addition, in June 2013, while Gaddafi was still nominally in power, the chairman of Libya's Transitional National Council (TNC), Mahmoud Jibril, visited Beijing: Emily O'Brien and Andrew Sinclair, 'The Libyan War: A Diplomatic History', Center on International Cooperation (New York: New York University, August 2011) p. 6.

61 S/PV.6711, 7 February 2012.

62 Matias Spektor, 'Intervenções no Brasil', Folha de S. Paulo, 19 March 2012,http://www1 .folha.uol.com.br/colunas/matiasspektor/1063756-intervencoes-do-brasil.shtml, accessed 18 February 2013 .

63 Kenkel, 'Brazil and R2P'. 
South Africa, for its part, has a long history of promoting $\mathrm{R}_{2} \mathrm{P}$ regionally, and in 2011, it even assumed leadership vis-à-vis Libya when it co-sponsored Resolution 1970 on February 26, which applied severe sanctions and condemned the Gaddafi regime for not stopping the violence against its own citizens. Russia, while rightly being seen as the most critical BRICS member vis-à-vis $\mathrm{R}_{2} \mathrm{P}$, has only played an obstructive role whenever its core national interests were at stake - such as in Syria, to which Russia sells arms, and which Moscow considers to be an important figure in the fight against terrorism in Southern Russia. Russian diplomats privately argue that the United States would be as unlikely to call for intervention were one of its key allies in the region - say, Saudi Arabia - home to large-scale killings. ${ }^{64}$ While it is too early to say whether these examples are signs of incipient socialization or norm diffusion, they are crucial to be taken into consideration when analysing emerging powers' views on $\mathrm{R}_{2} \mathrm{P}$.

\section{1: The BRICS in the UN Security Council}

Yet in order to gain a clearer understanding, a careful analysis of the BRICS' voting behaviour in the UN Security Council in 2011 is necessary. 2011 was a decisive year for the development of the Responsibility to Protect on the global stage. ${ }^{65}$ The UN Security Council mandates authorizing interventions in Libya and Côte d'Ivoire ${ }^{66}$ both explicitly made reference to the Responsibility to Protect. The Security Council did so in a unique constellation: during the year 2011 all BRICS members were represented on the Security Council. In addition to China and Russia as permanent members, Brazil, India and South Africa all held a rotating seat. This composition coincided with a host of international crises, thus providing observers with a series of meaningful case studies.

\section{February ${ }^{2} 6^{\text {th }}$ 2011: Resolution 1970}

Resolution 1970, called a 'strong resolution' by Susan Rice after the voting process, ${ }^{67}$ was the first to invoke the responsibility to protect with all the BRICS present in the UN Security Council. Aside from 'welcoming the condemnation by the Arab League, the African Union, and the Secretary General of the

\footnotetext{
64 Interview with Russian diplomats, June 17, 2012.

65 Alex J. Bellamy, Paul D. Williams, 'The new politics of protection? Côte d'Ivoire, Libya and the responsibility to protect', International Affairs, 87/ 4: 825-850 (July 2011); and Edward C. Luck, 'The Responsibility to Protect: The First Decade', Global Responsibility to Protect, 3:387-399 (2011).

66 S/RES/1973, 17 March 2011 and S/RES/1975, 30 March 2011.

67 S/PV.6491, 26 February 2011.
} 
Organization of the Islamic Conference of the serious violations of human rights and international humanitarian law that are being committed in the Libyan Arab Jamahiriya', the resolution recalled 'the Libyan authorities' responsibility to protect their population.' It also referred the situation in Libya since 15 February 2011 to the Prosecutor of the International Criminal Court (ICC) ${ }^{68}$ Aside from its South African sponsor, all BRICS countries voted in favour of the motion, even though India, China and Russia are not part of the International Criminal Court.

\section{March 17 ${ }^{\text {th }}$ 2011: Resolution 1973}

Resolution 1973 on Libya, passed on March 17, 2011, was the first time the UN Security Council approved the use of force against a functioning state in support of the Responsibility to Protect. $\mathrm{R}_{2} \mathrm{P}$ thus turned from an abstract idea into a highly visible foreign policy instrument. None of the BRICS countries voted against resolution 1973, which authorised a coalition of the willing NATO members to use 'all necessary' measures to protect civilians under threat in Benghazi. Brazil abstained in the vote alongside China, Russia, Germany and India. Despite the concerns raised by Brazil and others in the debate on the resolution, the BRICS' abstention came across as moderately supportive of the resolution. South Africa, in a surprise move, decided to support the resolution.

The Indian representative admitted to being seriously concerned about the situation in Libya, yet bemoaned that there was 'relatively little credible information on the situation on the ground in Libya. ${ }^{\prime} 9$ The Russian representative pointed out that Russia was a 'consistent and firm advocate of the protection of the civilian population.' He further argued that 'guided by this basic principle as well as by the common humanitarian values that we share with both the sponsors and other Council members, Russia did not prevent the adoption of this resolution.' At the same time, however, Russia remained convinced that the quickest way to ensure durable security for the civilian population and the 'long-term stabilization of the situation in Libya was an immediate ceasefire. ${ }^{70}$ China professed to be 'always against the use of force in international relations. China has serious difficulty with parts of the resolution' but assigns 'great importance to the relevant position by the 22-member Arab League on the establishment of a no-fly zone over Libya. ${ }^{.71}$ Finally, Brazil argued that its vote

\footnotetext{
68 UNSC Res. 1970, 26 February 2011.

69 S/PV.6498, 17 March 2011.

70 Ibid.

71 Bellamy, 'Libya and the Responsibility to Protect: The Exception and the Norm', p. 266.
} 
'should in no way be interpreted as condoning the behaviour of the Libyan authorities or as disregard for the need to protect civilians and respect their rights,' but argued that it was 'not convinced that the use of force as provided for in (...) the resolution will lead to the realization of our common objective - the immediate end to violence and the protection of civilians. ${ }^{72}$

This led Edward Luck to write that little or no opposition to the principle remains among the Member States. This was demonstrated at the July 2011 General Assembly dialogue on the role of regional and sub-regional arrangements in implementing the responsibility to protect, where support for the principle was repeatedly voiced despite the misgivings of some delegations about the way in which the air campaign to enforce Security Council resolution 1973 (2011) on Libya was being carried out. The critics' focus was on tactics, not on principles or strategies. ${ }^{73}$

Despite these ambivalent assertions after the voting on resolution 1973, it cannot be denied that non-Western actors, such as the League of Arab States and the Gulf Cooperation Council (GCC), played an important role in the months prior to the intervention in Libya. Without the Arab League, Organization of the Islamic Conference and GCC's initiative, the United States would not have supported the imposition of a no-fly zone. ${ }^{74}$ Also, had Brazil and South Africa voted against Resolution 1973, intervention would not have been possible given that nine votes in favour are necessary to pass a resolution by the Security Council (Res 1973 got 10 votes in favour and five abstentions).

But the BRICS' support for resolution 1973 soon vanished soon as the intervention began. While it voted in favour of the resolution, South Africa began to criticise the resulting NATO-led airstrikes. On March 22, only three days after the airstrikes began, China joined India and Russia in demands for a cease-fire, suggesting that allied forced were exceeding the UN's mandate by putting civilians at risk in Libya. ${ }^{75}$ Brazil's criticism also became more vocal. As the intervention lengthened, the BRICS's governments powerfully articulated the view at the UN that NATO was no longer acting as a defensive shield for populations at risk, but was merely pushing for regime change. ${ }^{76}$

72 S/PV.6498, 17 March 2011.

73 Edward Luck, 'The Responsibility to Protect: The First Decade'. p. 3

74 Alex J. Bellamy and Paul D. Williams, 'The new politics of protection? Côte d'Ivoire, Libya and the responsibility to protect', International Affairs, 87/4: 825-850 (2011).

75 O'Brien and Sinclair, 'The Libyan War,' p. 5 .

76 Simon Adams, 'Emergent Powers: India, Brazil, South Africa and the Responsibility to Protect', 20 September 2012, http://www.huffingtonpost.com/simon-adams/un-india -brazil-south-africa_b_1896975.html, accessed 18 February 2013. 
The intervention in Libya was hailed as a great success in the West. Ivo Daalder, the US ambassador to NATO, called it a 'model intervention: ${ }^{77}$ Stewart Patrick argued that it 'vindicated $\mathrm{R}_{2} \mathrm{P}^{\text {' }}{ }^{78}$ The BRICS disagreed. In a terse concept note submitted to the UN Secretary General in November 2011 referring to the Libya intervention, Brazil argued that 'there is a growing perception that the concept of the responsibility to protect might be misused for purposes other than protecting civilians, such as regime change. ${ }^{79}$ According to policy makers in Brasília, Pretoria and Delhi, NATO had abused emerging powers' good faith and turned Resolution 1973 into a mandate for removing Muammar Gaddafi from power. After Gaddafi's death in October 2011, Russia's Foreign Minister Lavrov yet again accused NATO of having overstepped the UN's mandate to protect civilians with the attack on Gaddafi himself - a concern that policy makers from all other BRICS countries shared. ${ }^{80}$ Thus, while Washington saw the Libya episode as a successful model for future humanitarian interventions, the BRICS saw it as a dangerous precedent.

\section{Resolutions 1991, 1996, 2000}

Yet in the meantime, on March $30^{\text {th }}$, all the BRICS voted in favour of a resolution that condemned the 'serious abuses and violations of international law in Côte d'Ivoire, including humanitarian, human rights and refugee law' and reminded the government of Côte d'Ivoire of its responsibility to protect its citizens. ${ }^{81} \mathrm{~A}$ month later, the BRICS again collectively voted in favour of a resolution that reminded the Government of the Democratic Republic of the Congo of its responsibility to ensure security in its territory and protecting its civilians with respect for the rule of law, human rights and international humanitarian law. ${ }^{82}$ On July 8 , the BRICS in unison promised to 'advise and assist the Government of the Republic of South Sudan, including military and police at national and local levels as appropriate, in fulfilling its responsibility to protect civilians. ${ }^{\prime 83}$ The resolution had been co-submitted by South Africa.

77 Ivo H. Daalder and James G. Stavridis, 'NATO's Victory in Libya: The Right Way to Run an Intervention', Foreign Affairs, 91/3: 2-7 (2012).

78 Stewart Patrick, 'Libya and the Future of Humanitarian Intervention: How Qaddafi's Fall Vindicated Obama and RtoP', Foreign Affairs, 26 August 2011.

79 RwP concept paper. The concept paper was, wrongly, seen by many as written in opposition to $\mathrm{R}_{2} \mathrm{P}$.

8o Emily O'Brien and Andrew Sinclair, 'The International Role in Libya's Transition', Center on International Cooperation, New York University, July 2012, p. 15.

81 S/RES/1975, 30 March 2011.

82 S/RES/1991, 28 June 2011.

83 S/RES/1996, 8 July 2011. 
China's support for the resolution was particularly noteworthy given its significant economic interests in Sudan. The BRICS were equally supportive of a resolution that 'strongly condemned the atrocities, serious human rights abuses and violations as well as violations of international humanitarian law that occurred throughout the post-elections crisis in Côte d'Ivoire, voted on in late July $2011 .^{84}$

\section{Syria}

On August 2, 2011, the China Daily announced that 'BRICS nations are to vote against Syria resolution, ${ }^{85}$ citing the Moscow-based RIA Novosti news agency. Yet only a day later, China and Russia proved to be the only BRICS members to reject the General Assembly Resolution $66 / 253 \mathrm{~B},{ }^{86}$ which directly criticises Russia and China by 'deploring the Security Council failure' to act. In addition, the resolution supported Annan's 'demand that the first step in the cessation of violence has to be made by the Syrian authorities'. This was the main reason for India to abstain, arguing that the text made scant mention of the role of the armed opposition, which was setting a 'dangerous trend' by using weapons of 'very high sophistication,' in the violence. Brazil and South Africa supported the resolution. ${ }^{87}$

\section{October 4, 2011 - the BRICS Veto and Abstain from a Resolution Against Syria}

Two months later, China and Russia vetoed a draft resolution, sponsored by France, Germany, Portugal and the UK, which condemned the Syrian crackdown on protestors. ${ }^{88}$ Brazil, India and South Africa abstained. Several rounds of negotiations had substantially softened the text. However, language on the Council's intent to consider further measures if the Syrian regime failed to implement the resolution's provisions remained. Strongly influenced by the negative experience with the intervention in Libya two months earlier, both Russia and China vetoed the draft S/2011/612, while Brazil, India and South Africa abstained. 'More disappointing, but sadly predictable, were the decisions

\footnotetext{
84 S/RES/2000, 27 July 2011.

85 Zhao Shengnan, 'BRICS nations to vote against Syria resolution,' o2 August 2012, www .chinadaily.com.cn/world/2012-08/02/content_15639447.htm, accessed 22 July 2013.

86 A/66/L.57, 31 July 2012.

87 Sandeep Dikshit, 'No mention of opposition violence in Syria resolution,' 5 August 2012, www.thehindu.com/news/international/no-mention-of-opposition-violence-in-syria -resolution/article3728284.ece, accessed 22 July 2013. 
by India, Brazil and South Africa to abdicate responsibility', 89 Stewart Patrick argued, calling it a 'sad example of the failure of the world's large emerging democracies to live up to their domestic values and assume the responsibilities of power. ${ }^{90}$ The abstainers' decision to participate in a mission to Damascus to urge the Bashar al-Assad regime to stop the violence against his own citizens, while also asking the opposition to interrupt the conflict, did little to assuage critics. $^{91}$

The Russian representative made reference to attempts by the BRICS states to develop a parallel draft resolution, and criticised the one voted on as being written according to 'the philosophy of confrontation' and that Russia cannot agree with this unilateral, accusatory bent against Damascus. Most importantly, he explicitly referred to the anger about the way the Libya intervention was conducted. ${ }^{92}$ This was aligned with comments made privately by Indian and South African diplomats after the voting process. ${ }^{93}$ The Chinese representative limited himself to arguing that under the current circumstances, sanctions or the threat thereof would not help to resolve the question of Syria. Brazil explained its abstention as a protest against the posturing and division amongst the five permanent Security Council members. In her explanation of Brazil's vote, the Brazilian UN ambassador Maria Luiza Viotti also argued that 'Brazil stands in solidarity with the aspirations expressed by the populations in many Arab countries for greater political participation, economic opportunities, freedom and dignity. (...) Brazil has unequivocally condemned human rights violations, wherever they occur. ${ }^{94}$ Yet Brazil chose not to support the European initiative for condemning human rights violations (and threatening sanctions that exclude military action). ${ }^{95}$ The Indian representative Singh Puri argued that the resolution did not condemn the violence perpetrated by the Syrian opposition, nor does it place any responsibility on the opposition to abjure violence and engage with the Syrian authorities for redress of their grievances through a peaceful political process. ${ }^{96}$ Meanwhile, the justification

89 Stewart M. Patrick, 'No Profile in Courage: Syria, BRICS, and the UNSC', 5 October 2011,http://blogs.cfr.org/patrick/2011/10/05/no-profile-in-courage-syria-brics-and-the -unsc/, accessed 18 February 2013.

9o Ibid.

91 Spektor, 'Humanitarian Interventionism Brazilian Style?'.

$92 \mathrm{~S} / 2011 / 612,4$ October 2011.

93 Conversations with South African and Indian diplomats, 2012.

94 S/PV.6627, 4 October 2011.

95 S/PV.6627, 4 October 2011.

96 S/2011/612, 4 October 2011. 
from South Africa's Ambassador to the UN, Baso Sangqu, was that with regard to Syria the 'trajectory, the templates for the solution were very clear; it was along similar lines to Libya'. Or in other words, India, Brazil and South Africa were not condoning Assad's crimes, but avoiding a slippery slope to military intervention..$^{97}$

Considering how often the BRICS supported resolutions in support of $\mathrm{R}_{2} \mathrm{P}$ during their joint time on the UNSC, it would be wrong to overly focus on China's and Russia's uncooperative behaviour regarding Syria and allow it to symbolise the BRICS' stance on R2P. In fact, the UNSC referred to R2P more often in the 12 months after the intervention in Libya than in the five years prior to Resolution 1973. Deplorable as Russia and China's opposition to a condemnation against the Syrian regime may be, Michael Ignatieff's prediction that 'Syria tells us that the era of humanitarian intervention, 'responsibility to protect,' is over'98 does not seem to take the BRICS' voting record in the UNSC into account. Syria was clearly the exception, not the rule.

\section{Resolutions 2014, 2016, 2021, 2030, 2031}

Less than three weeks later, all the BRICS voted in favour of a resolution calling on the Yemeni government to protect its population. This strongly worded resolution condemned the continued human rights violations by the Yemeni authorities, such as the excessive use of force against peaceful protestors as well as the acts of violence, use of force, and human rights abuses perpetrated by other actors, and stressed that all those responsible for violence, human rights violations and abuses should be held accountable. ${ }^{99}$ Still in the same month, the BRICS collectively voted in favour of resolution 2016, which mentioned the Libyan government's responsibility to protect its population, and 'strongly urges' the Libyan authorities to refrain from reprisals, including arbitrary detentions. ${ }^{100}$ In the same way, the BRICS supported resolutions that urged the DRC's government (in November), ${ }^{101}$ the Burundian government, ${ }^{102}$ and the government of the Central African Republic ${ }^{103}$ (in December) to honour their responsibility to protect their respective populations.

\footnotetext{
97 Adams, 'Emergent Powers: India, Brazil, South Africa and the Responsibility to Protect'.

98 Ignatieff, 'How Syria Divided the World'.

99 S/RES/2014, 21 October 2011.

$100 \mathrm{~S} / \mathrm{RES} / 2016,27$ October 2011.

$101 \mathrm{~S} / \mathrm{RES} / 2021,29$ November 2011.

$102 \mathrm{~S} / \mathrm{RES} /$ 2030, 21 December 2011.

103 S/RES/2031, 21 December 2011.
} 


\section{November 11, 2011: Brazil and the Responsibility While Protecting (RwP) Concept}

In November 2011, a month before leaving the UN Security Council, Brazil's United Nations delegation presented a concept note proposing RWP to the UN Security Council. This came only days after the end of the North Atlantic Treaty Organization (NATO) operation in Libya and the killing of Libya's former president, Muammar Gaddafi. ${ }^{104}$ The RWP concept stopped short of specifying how to roll out the criteria it proposed. Brasília conceived it less as a finished doctrine and more as a broad message to the international community: if humanitarian interventions in the future remain loosely regulated and big power coalitions intervene as they please, then $\mathrm{R}_{2} \mathrm{P}$ will divide the international community between north and south, rich and poor, strong and weak. Western capitals reacted largely negatively, as RwP was seen as an attempt to obstruct future interventions. Yet they misunderstood: Brazil's intention was not to undermine $\mathrm{R}_{2} \mathrm{P}$ - rather, it was a genuine attempt to strengthen the debate and consider emerging powers' concerns. Largely thanks to Brazil's Foreign Minister Antonio Patriota's personal interest in the issue, it was temporarily 'impossible to speak about humanitarian intervention in New York without mentioning Brazil's initiative.'105 While Brazil still officially embraces its concept, it no longer seems to be a foreign policy priority, partly since Brazil left the UN Security Council soon after launching the initiative.

\section{The BRICS and the R2P's Three Pillars}

Regarding pillar $\mathrm{I}^{106}$ emerging powers' and established powers' views are largely aligned. Discussing China's thinking on the application of R2P, Liu Tiewa points out that 'with regard to the three pillars embodied in the concept of RtoP, the Chinese government has tended to be more supportive of pillar one: the protection responsibility of the state.'107 While many analysts around the world are anxious about China's rise, China's impact on a global level has most likely been positive - largely by lifting millions of people at home and abroad out of poverty. In a similar fashion, Brazil, India, Russia and South Africa agree with pillar I in the sense that it actually strengthens, rather than weakens, the state actors in international affairs.

104 Xenia Avezov, 'Responsibility while protecting': are we asking the wrong questions?', 13 January 2013,http://www.sipri.org/media/newsletter/essay/Avezov_Janı, accessed 19 February 2013.

105 Interview with Simon Adams, Global Center for the Responsibility to Protect, April 2013.

106 States have the primary responsibility to protect their populations from genocide, war crimes, ethnic cleansing and crimes against humanity.

107 Liu, 'China and Responsibility to Protect', p. 166. 
The above analysis shows that in addition to pillar I, the BRICS are fully in accordance with Pillar $\mathrm{II}^{108}$ - and in fact, the majority of BRICS countries are actively involved in combating the root causes of genocide, war crimes, ethnic cleansing and crimes against humanity. India, for example, has made massive human contributions to UN peacekeeping missions for decades, including those under Chapter VII. In the same way, China contributes to promoting development and peace abroad, through its leadership in peacekeeping (as the largest troop contributor of the $\mathrm{P}_{5}$ ) and development aid. ${ }^{109}$ The BRICS position supports thus what pillar I and II describes: primary state responsibility and the development of cooperation measures to help in prevention, which should not be diminished in relation to the third pillar (action by the international community, including force). ${ }^{110}$

While the BRICS fully agree with the principles laid out in pillar I and II, it is regarding pillar III'11 that there is a gap between NATO and the BRICS. For example, Liu Tiewa's asserts that from the Chinese government's point of view, 'action can only be taken with the consent of the state involved'. Yet she also quotes a Chinese policy maker who concedes that 'absolute non-interference' is not possible. Liu sums up these seemingly contradicting positions by arguing that 'China has gradually changed its general attitude towards humanitarian intervention from absolute non-intervention by the international society to conditional international intervention.112

Contrary to Pillar I, which is quite specific in nature, Pillar III is indeterminate and open-ended. This means that beyond a minimum expectation that national governments should not assist violent perpetrators, it is usually not clear what exactly R2P requires in a specific situation. ${ }^{113}$ From the BRICS' point of view, the lack of determinacy of Pillar III holds a significant risk that Western powers could misinterpret and overextend the norm - one of the reasons that policy makers in the BRICS have often felt uncomfortable agreeing to pillar III. Yet, rejection is far from absolute. For example, the Brazilian

108 Addresses the commitment of the international community to provide assistance to States in building capacity to protect their populations from genocide, war crimes, ethnic cleansing and crimes against humanity and to assisting those which are under stress before crises and conflicts break out World Summit Outcome.

109 Liu, 'China and Responsibility to Protect', p. 166.

110 Kenkel, 'Brazil and $\mathrm{R}_{2} \mathrm{P}$ '.

111 Focuses on the responsibility of international community to take 'timely and decisive action' to prevent and halt genocide, ethnic cleansing, war crimes and crimes against humanity when a State is 'manifestly' failing to protect its populations.

112 Liu, 'China and Responsibility to Protect'. p. 166

113 Bellamy, Global Politics and the Responsibility to Protect. From Words to Deeds, p. 86. 
government clearly argues that 'there may be situations in which the international community might contemplate military action to prevent humanitarian catastrophes.' ${ }^{114}$

The BRICS governments are critical of pillar III because they continue to believe that $\mathrm{R}_{2} \mathrm{P}$ cannot be threatened or imposed externally because it can cause the isolation and the deepening of the crisis. Rather than intervening militarily, abusive governments should be 'engaged and cajoled', as Landsberg puts it. ${ }^{115}$ This strong preference for diplomacy over using force is a striking similarity between all the BRICS - as is the belief, as Kenkel writes, that it is possible to assume global responsibility without using force. ${ }^{116}$ Preventive efforts, on the other hand, are, as the BRICS argue, far less invasive and less promising, such as peacekeeping, good governance and development - all key determinants of the BRICS' foreign policy guidelines. These ideas are enshrined in pillar II: Conflicts are impossible to solve for good unless root causes - such as poverty and inequality - are addressed in a meaningful way. This, of course, does not address the question about what should be done once diplomacy and preventive efforts have failed to prevent violence.

In addition, pillar III continues to be seen in a critical manner by BRICS analysts and policy makers because of enforcement capacity of the concept's pillar III - namely, the responsibility to intervene if a government fails to protect its citizens. The BRICS do not equate assuming responsibility to the use of force, thus fundamentally contradicting a Western modus operandi. As Brazil's Ambassador to the UN, Viotti, put it in 2011, 'even when warranted on the grounds of justice, legality and legitimacy, military action results in high human and material costs.'117

\section{What Does this Mean for the Future of $\mathrm{R}_{2} \mathrm{P}$ ?}

As this analysis shows, the BRICS and the West are largely aligned with regard to pillar I and pillar II of the $\mathrm{R}_{2} \mathrm{P}$ concept. They also agree - in theory - on most of the ideas expounded in pillar III, yet they have differences about what exactly to do when a government 'manifestly' fails to protect its citizens. As a consequence, they have, as the analysis above shows, agreed to apply $\mathrm{R}_{2} \mathrm{P}$ in

\footnotetext{
114 A/66/551-S/2011/701, 11 November 2011, p. 3, paragraph 8.

115 Landsberg, 'Pax South Africana and the Responsibility to Protect', p. 443.

116 Kenkel, 'Brazil and R2P'.

117 A/66/551-S/2011/701, 11 November 2011, p. 1, para. 7.
} 
most cases during the period of analysis. The BRICS' ambivalence about Syria is therefore an exception, not the rule. ${ }^{118}$

The BRICS' ambivalence about some cases of $\mathrm{R}_{2} \mathrm{P}$ should not be mistaken for a lack of commitment to the protection of civilians - even though this is precisely what many observers tend to do. India, it is worth remembering in this context, was the first country to formally raise the issue of Apartheid at the UN, putting it on the world body's agenda in 1946. Brazil hosted the first major UN seminar on apartheid in 1966, an event that fed into an initiative in the General Assembly to diplomatically isolate the apartheid regime.

Rather, the BRICS' ambiguity regarding the West's eagerness to apply $\mathrm{R}_{2} \mathrm{P}$ in the case of Syria needs to be understood within broader criticism of today's global order. Why, Brazilian policy makers ask privately, did Libya qualify as a case of R2P, but not Gaza in 2008 where according to the impartial Goldstone report war crimes were committed by both Israel and Hamas? Why was there no talk about an intervention in Bahrain, which is closely aligned with the United States? Why was Kenya an $\mathrm{R} 2 \mathrm{P}$ case, but not Somalia? What about Darfur, Afghanistan and Iraq, countries in which more than 50,00o civilians have been killed in each over the past decade? There is a clear contrast between universal language and selectivity when it comes to engaging in crises, which points to worries in Beijing, Delhi, Pretoria, Moscow and Brasília that the West only cares about protecting civilians when it is aligned with other economic or strategic interests. As Bellamy observes, 'while there is growing consensus about the RtoP in principle, in practice RtoP is applied selectively and inconsistently and its use is often contested."119 In addition, questions about French violations of the arms embargo against Libya and 2011 have rightly led several BRICS governments to argue that better oversight and more transparency is necessary during future operations.

At the same time, one must recognise that emerging powers' rhetoric is similarly inconsistent - as would be expected in any foreign policy debate where liberal principles clash with realpolitik. There are many legitimate questions for the BRICS vis-à-vis $\mathrm{R}_{2} \mathrm{P}$ that remain unanswered. Chinese officials profess to focus on prevention, yet what should be done if prevention fails? What kind of prevention could have avoided the conflict in Libya, a country that only a few weeks before gave no signs of being a potential victim of large-scale killings? How can China become a thought leader in prevention? The Chinese government insists that force should almost never be used against the will of

\footnotetext{
118 In addition, it is far from clear whether France, the United Kingdom and the United States would push for interventions were Russia not to block more critical UNSC resolutions.

119 Bellamy, Global Politics and the Responsibility to Protect. From Words to Deeds, p. 71.
} 
the host government, yet it does not formulate when exactly this rule can be broken to save civilians.

Still, the common perception that the BRICS are only now beginning to develop more sophisticated ideas about global norms and sovereignty is mistaken. China, for example, has a 'semi-feudal and semi colonial' history as Liu Tiewa points out, which strongly informs its position on sovereignty and intervention. ${ }^{120}$ In the same way, India's foreign policy identity rests on its traumatic experience of colonization and the subsequent battle for independence. In a very similar fashion, Brazil has long sought to strengthen sovereignty on the multilateral level, conscious of the fact that it was the weapon of the weak. The BRICS are thus not 'beginning to make up their minds' about the big questions of the day - rather, their recent rise both allows and forces them to engage more than before.

Yet emerging powers' participation in the debate is crucial. What is the connection between economic development, democratization and $\mathrm{R}_{2} \mathrm{P}$ ? How important is early warning, and which role do regional organizations play? These are crucial questions, particularly because emerging powers have recently emphasised that the focus of $\mathrm{R}_{2} \mathrm{P}$ must be prevention.

\section{Conclusion}

As this brief analysis shows, the BRICs' position vis-à-vis the Responsibility to Protect is often misunderstood. While it is popular to depict emerging powers as 'revisionist', 'irresponsible'121 or 'shirkers', ${ }^{122}$ today's emerging powers have played an important part in the process of turning $\mathrm{R}_{2} \mathrm{P}$ into a global norm. As Monica Serrano rightly argues, just 'because half a dozen countries continue to object to $\mathrm{R} 2 \mathrm{P}$, observers go on concluding that $\mathrm{R}_{2} \mathrm{P}$ is controversial ${ }^{123}$ - yet these countries are often relatively small and unable to gain many followers. The vast majority of critiques made by BRICS governments are legitimate and constructive, and it would be wrong to judge them as opposed to $\mathrm{R}_{2} \mathrm{P}$ in principle.

\footnotetext{
120 Liu, 'China and Responsibility to Protect'. p. 159

121 Stewart Patrick, 'Irresponsible Stakeholders? The Difficulty of Integrating Rising Powers', Foreign Affairs, 89/6: 44-53 (2010).

122 Randall Schweller, 'Emerging Powers in an Age of Disorder', Global Governance, 17/3: 285-297 (July-September 2011).

123 Mónica Serrano, 'The Responsibility to Protect: True Consensus, False Controversy', Development Dialogue, 55: 101-110 (2010), p. 110.
} 
Despite this, $\mathrm{R} 2 \mathrm{P}$ is routinely seen as a Western concept by many analysts from the Global North and the Global South. There are several reasons why the West seems to 'own' R2P. First of all, the academic debate about the Responsibility to Protect is fundamentally a Western one, and non-Western scholars like Francis Deng and Ramesh Thakur are exceptions. The majority of leading thinkers and proponents on the topic - Gareth Evans, Alex Bellamy, Jennifer Welsh, Edward Luck, Michael Ignatieff, and so on - are all from the so-called 'Global North' (although this phenomenon is not limited to $\mathrm{R}_{2} \mathrm{P}$ but to International Relations more generally).

In a recent article, Thomas Weiss and Rama Mani state that:

Western scholars have produced most of the seminal work that has influenced the development of $\mathrm{R}_{2} \mathrm{P}$ - in conflict prevention, crisis management, peace-building, human rights, and international humanitarian law. In parallel, the voluminous reflections and publications by scholars across the global South are unavailable even in world-class, research-university libraries in North America and Europe; they are inaccessible to policy makers in the North and in the South. ${ }^{124}$

In addition, $\mathrm{R}_{2} \mathrm{P}$ is often misunderstood as being all about humanitarian intervention as seen in Libya, an area clearly dominated by the West. Yet of the concept's three pillars, only the third is partially about intervention, and the rest is about the far more important aspect of prevention. Prevention gets far less media coverage than intervention, so India, China and Brazil's (significant) peacekeeping efforts over the past years - fully aligned with $\mathrm{R}_{2} \mathrm{P}$ - have probably generated fewer media reports than NATO's military intervention in Libya. As a consequence, the BRICS are often wrongly seen as unsupportive of $\mathrm{R}_{2} \mathrm{P}$.

Finally, emerging powers may prefer to depict $\mathrm{R}_{2} \mathrm{P}$ as a foreign concept to which they reluctantly agreed, as this may increase their room for political manoeuvre and to occasionally distance themselves from the idea if they believe it misinterpreted, as was the case in 2011 with Libya. This is particularly important since the operational capacity to actually intervene if necessary is distributed unevenly. As O'Brien's and Sinclair's analysis makes clear, the United States' military role in the Libya intervention was far more important than the Obama administration sought to project. ${ }^{225}$ This shows that the US is de facto the only country that is capable of organizing large-scale interventions in the name of R2P.

124 Weiss and Mani, 'R2P's Missing Link, Culture', pp. 451-472.

125 O'Brien and Sinclair, 'The Libyan War'. 
This situation will change only once BRICS develop a greater capacity to not only assume leadership in preventive efforts that are part of $\mathrm{R}_{2} \mathrm{P}$ (peacekeeping, development, etc.), but also in the use of force to protect civilians (a small but highly visible element of the Responsibility to Protect) - as seen in Libya. Until then, using force in the name of $\mathrm{R}_{2} \mathrm{P}$ against the will of a functioning state will be seen as a largely Western endeavour. 